\title{
Options for reducing external costs from freight transport along the Brenner corridor

Silvio Nocera ${ }^{1 *}$, Federico Cavallaro ${ }^{1,2}$ and Olga Irranca Galati ${ }^{1}$

\begin{abstract}
The Brenner is the most heavily travelled transalpine corridor in terms of freight transport. The current modal split tends heavily towards road (71\% road - 29\% rail), with significant repercussions in terms of environmental and social impacts. Indeed, Alpine areas generate external costs that are up to four times higher than flat areas. The promotion of railway, which is the least impacting transport mode, has thus a strategic value. For this reason, the European Union, the Alpine macro-region and the Tyrol-South Tyrol-Trentino Euroregion are promoting multi-level strategies to reduce the impact generated by freight transport along the Brenner corridor. This paper analyses each level, focussing then on the Euroregion. Its ambitious objective is to achieve a balance between transport modes in the Alpine corridor by 2027 , and then to invert them (29\% road $-71 \%$ rail) by 2035 . This paper aims to calculate the savings of external costs deriving from the achievement of this objective. If the aggregated data from 2015 to 2035 are considered and the Euroregion scenario is compared with a prosecution of the

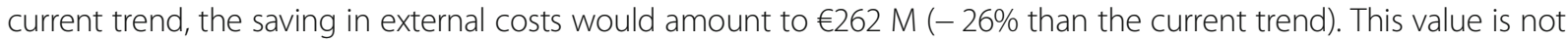
negligible; being equal to $4.7 \%$ of the annual public expenditure incurred by the Autonomous Province of Bolzano, it suggests to policy makers the importance of taking up measures to encourage the modal shift.
\end{abstract}

Keywords: Freight transport, Economic valuation, External costs, Brenner corridor, Transport policies

\section{Introduction}

The volume of internal freight transport in Europe amounts to approximately 2300 billion tkm [1]; 75.3 and $18.3 \%$ of them are transported, respectively, by road and by rail. With $86.5 \%$ of its total tkm transported by road and a mere $13.4 \%$ by rail $(0.1 \%$ via inland navigable waters), Italy ranks as one of the lowest European countries - far from Latvia's lead (nearly $80 \%$ by rail). In Europe, the transport industry accounts for $28.5 \%$ of total $\mathrm{CO}_{2}$ emissions [2]. Of road emissions, $38 \%$ is produced by freight transport. Transport, in addition to being responsible for approximately one third of total $\mathrm{CO}_{2}$ emissions and energy consumption in the European Union (EU), is also cause of other external effects such as congestion, noise pollution, air pollution and accidents, which have a direct impact on citizens' lives.

Among terrestrial systems, numerous reports indicate rail as the most sustainable one, capable of promoting a

\footnotetext{
* Correspondence: nocera@iuav.it

'Department of Architecture and Arts, IUAV University of Venice, Santa Croce 191, I-30135 Venice, Italy

Full list of author information is available at the end of the article
}

reduction in the external costs resulting from freight transport without curbing mobility [3-7]. Also the scientific literature that deals with modal shift and the related reduction of transport externalities is vast [8-15]. It confirms the importance of a balanced system, where rail transport should have a more preeminent role. For this reason, the EU has defined a strategy to rebalance the transport modes, reducing the road component. In the Transport White Paper [16], the main objective is to transfer $30 \%$ of freight currently carried out by road to other transport modes, such as rail and inland waters by 2030 and $50 \%$ by 2050 .

In the Alpine context, promoting rail freight transport has even a greater value: its mountainous geomorphological conformation can generate external costs that are up to four times higher than flat areas [17]. However, promoting railway entails numerous critical issues, such as the technical difficulties in constructing new railway infrastructures. Furthermore, the differences in the policies and measures introduced along the Alpine arc has, over time, created a disproportion in the distribution of flows between the corridors. 
Considering the volume of traffic along the five main transalpine axes, in 2015, 42\% crossed Brenner, 26\% Gotthard, 17\% Tarvisio and only 15\% the Italian-French corridors of Mont Blanc and Fréjus. The modal split varies considerably, in accordance with the policies adopted by the single countries. Simply sharing infrastructural decisions at a European level, although necessary, is not sufficient to guarantee a positive result towards the use of rail for freight transport.

This article focuses on the condition of Brenner, the most travelled corridor in the Alps. Nearly 44 million tonnes of goods are transported every year via Brenner; of these, less than $30 \%$ are transported by rail. This leads to systematically exceeding $\mathrm{NO}_{2}$ limits and a series of negative consequences for populations living nearby [18]. In light of this condition, the Tyrol-South TyrolTrentino Euroregion (core of the Brenner corridor) has established more ambitious objectives than those set at the EU level: balancing the transport modes by 2027 and reversing them by 2035 [19]. This paper has the double objective of providing exploratory and interpretative support to the various existing measures in order to facilitate the shift towards rail, and calculating the environmental benefit, in terms of external costs (local and global pollutant emissions, noise, congestion and accidents), of achieving Euroregional objectives. Furthermore, the analysis of the Brenner corridor demonstrates the need for more coordination between the different policy levels, in order to obtain a higher modal shift towards rail.
The article is structured as follows: Section 2 provides a description of the Brenner corridor from a geographical and infrastructural perspective. Section 3 provides a general overview of the policies proposed at European, Alpine and Euroregional levels to facilitate the modal shift. Section 4 proposes an overview of potential or existing measures applied to achieve the specified objectives. Section 5 presents a calculation of the external costs deriving from the implementation of the Euroregion strategy and the resulting environmental benefit compared to the status quo. Lastly, Section 6 summarises the main topics and the political implications generated by specific transport measures.

\section{The Brenner corridor: Geographical and infrastructural framework}

The Brenner corridor is the central part of the MunichVerona corridor, which is part of the north-south E45 European backbone connecting Finland to Italy and Malta. It is the most important pass on a European level, considering the average number of transiting freight and passenger vehicles -8908 and 18,846 vehicles respectively per day in 2015 [18] - and the fair morphological conditions (1378 $\mathrm{m}$ above sea level and a lower incline than other Alpine passes). Infrastructurally, the Brenner corridor is composed by the Brenner railway line (Verona-Brenner), the A22 Motorway (ModenaBrenner) and the SS12 state road (Table 1). The railway line constitutes $120 \mathrm{~km}$ of the total network in South Tyrol $(290 \mathrm{~km})$ and it is the only line run by

Table 1 Main infrastructures constituting the Brenner corridor

\begin{tabular}{|c|c|c|c|c|c|}
\hline Infrastructure & Length & Management & Infrastructural features & Limits set & Ongoing projects \\
\hline Brenner Railway & 120 km & $\begin{array}{l}\text { Rete Ferroviaria Italiana (RFI) } \\
\text { [Italian Railway Network] }\end{array}$ & $\begin{array}{l}\text { Structure: double track; } \\
\text { Gauge: } 1435 \text { mm; } \\
\text { Power supply: electricity } \\
\text { (3000 V); } \\
\text { Stations: } 15 \text { (4 main; } 6 \\
\text { intermediate; } 5 \text { local); } \\
\text { Maximum slope: } 25 \% 0\end{array}$ & $\begin{array}{l}\text { Varies according to train } \\
\text { classification }\end{array}$ & $\begin{array}{l}\text { New High-Capacity/High- } \\
\text { Speed Helsinki-La Valletta } \\
\text { Palermo Railway, Brenner } \\
\text { Base Tunnel }\end{array}$ \\
\hline A22 Motorway & 116 km & $\begin{array}{l}\text { Autostrada del Brennero } \\
\text { S.p.A. }\end{array}$ & $\begin{array}{l}\text { Structure: dual carriageway, } 2 \\
\text { lanes in each direction } \\
\text { Maximum slope: } 45.9 \% 0 \\
\text { Tollbooths: } 24 \\
\text { Safety Centres: } 6 \\
\text { Service Centres: } 6 \\
\text { Service Areas: } 22 \\
\text { Variable Message Signs: } 105\end{array}$ & $\begin{array}{l}\text { Light vehicles: } \\
130 \mathrm{~km} / \mathrm{h} \text { (Modena- } \\
\text { Bolzano); } \\
110 \mathrm{~km} / \mathrm{h} \text { (Bolzano-Brenner) } \\
\text { Heavy vehicles: } \\
80 \mathrm{~km} / \mathrm{h} \\
60 \mathrm{~km} / \mathrm{h} \text { (between } 54 \mathrm{~km} \\
\text { and } 85 \mathrm{~km} \text { ) }\end{array}$ & $\begin{array}{l}\text { BrennerLEC (2015-2021) } \\
\text { C-ROADS Italy (2017-2020) } \\
\text { URSA MAJOR II (2014-2018) }\end{array}$ \\
\hline SS12 state road & 120 km & $\begin{array}{l}\text { Autonomous Province } \\
\text { of Bolzano }\end{array}$ & $\begin{array}{l}\text { Structure: single carriageway, } \\
1 \text { lane in each direction } \\
\text { Maximum slope: } 45.9 \% \text { o } \\
\text { Connections with the A22 } \\
\text { motorway: } 9 \\
\text { Traffic detection stations: } 11\end{array}$ & $\begin{array}{l}\text { Light vehicles: } \\
90 \text { km/h (variable) } \\
\text { Heavy vehicles: } \\
80-50 \text { km/h Brenner- } \\
\text { Vipiteno (maximum limit of } \\
20 \text { t southbound) } \\
80-50 \text { km/h Bressanone } \\
\text { Varna-Bressanone Albes: } \\
\text { maximum limit of } 7.5 \mathrm{t}\end{array}$ & $\begin{array}{l}\text { Risk mitigation works } \\
\text { Ring roads and Bressanone, } \\
\text { Varna, Bronzolo, Laives, and } \\
\text { Pineta di Laives tunnels }\end{array}$ \\
\hline
\end{tabular}


freight trains. The SS12 state road overall measures $520 \mathrm{~km}$ and is divided into three main stretches; the first part from north belongs to South Tyrol and goes from the Brenner pass to Salorno $(120 \mathrm{~km})$. Lastly, the A22 Motorway (116 km in South Tyrol) is one of the most important motorways in Italy, as it connects the national network to Austria and Germany. In Italy, it intercepts the A1 (Milan-Rome) near Modena and the A4 (Milan-Venice) near Verona. These three infrastructures are summarised in the multimodal transport graph (Fig. 1), which shows the entire South Tyrolean territory and indicates the average costs and travel times. Table 1 shows the main infrastructural and management features of each infrastructure, as well as the ongoing projects that aims at improving their levels of service.

Referring to the freight volumes, in 2015, Brenner recorded the highest numbers for average daily heavy

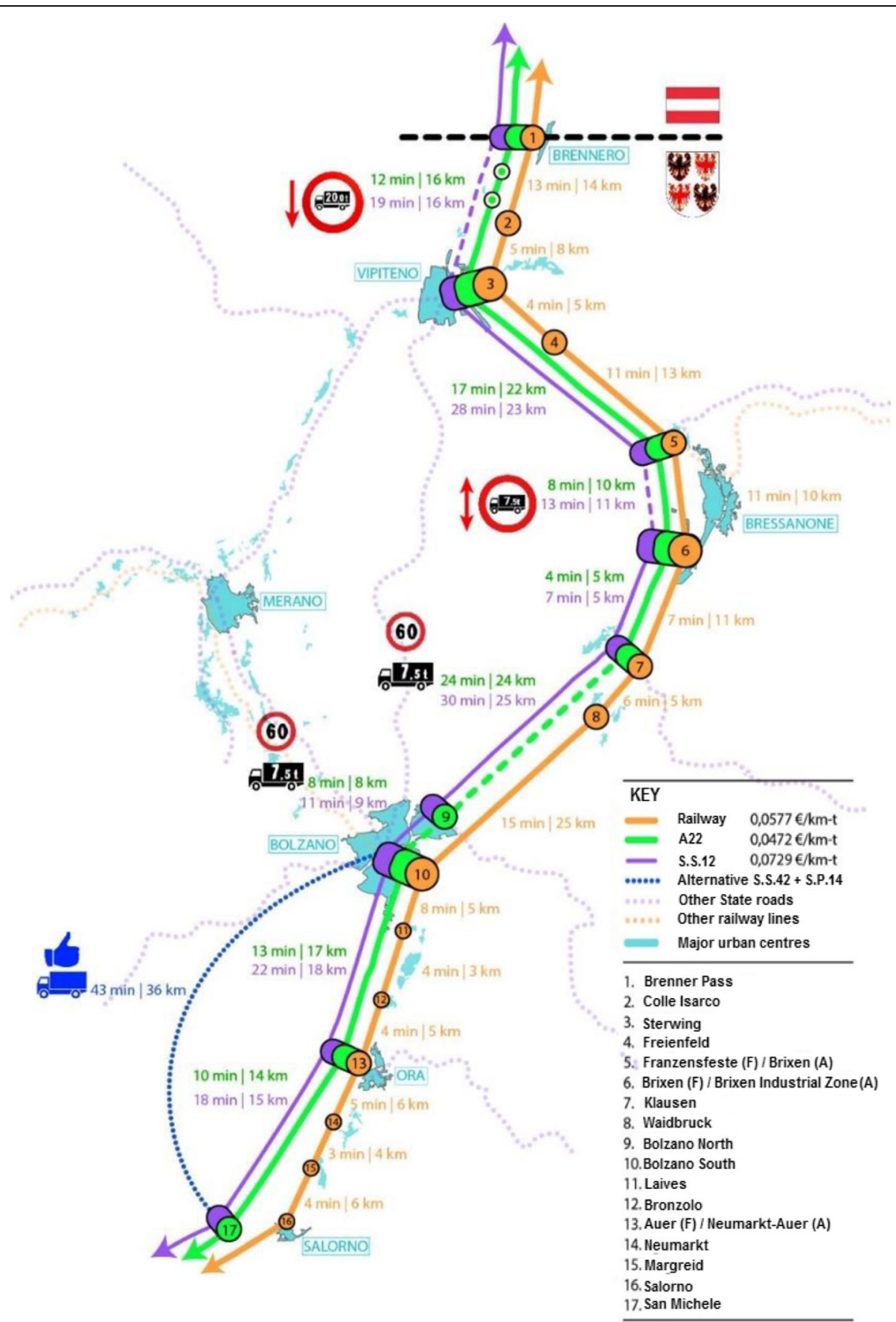

Fig. 1 The Brenner corridor: transport infrastructures in South Tyrol and costs for HGVs 
vehicle traffic ( 8908 vehicles/day), with more than twice the number of vehicles of Tarvisio (3464 vehicles/day) and Gotthard (3978 vehicles/day) - up 3.5\% from 2014 and showing a growing trend [18]. In absolute terms, the Brenner corridor registered an increase in the total volume of freight transport (by both train and heavy vehicles, from 42.6 Mt. to 43.9 Mt. in 2015). The modal split still tends noticeably towards the road, with only $29 \%$ of goods transported by rail. By comparison, the Gotthard axis has the reverse of the Brenner corridor split: $63 \%$ by rail and $37 \%$ by road.

\section{Political and legislative framework}

Three levels of international management and coordination of freight transport influence the Brenner corridor, each with specific responsibilities: the European Union, the Alpine Region and the Tyrol-South Tyrol-Trentino Euroregion (Fig. 2). The first level defines the general transport objectives at continental level and for each Member State. The White Paper on Transport [16] explains the reasons for increasing investments in the railway system by the European Union. They include moves towards sustainable transport modes with lower environmental impact, the development of a single supranational railway network that contributes to strengthen the European Single Market, and ultimately, growth in economy and employment. The second level coordinates all countries that have a part of their territory in the Alpine arc and share similar needs from an economic, social and environmental standpoint. The third is derived from a collaboration project among the regions belonging to the historical Tyrol - Tyrol itself (an Austrian federal state), Trentino and South Tyrol (both Italian autonomous provinces) - with the aim of facilitating cross-border, transnational and inter-regional cooperation.
The Autonomous Province of Bolzano and the other regions of the Euroregion are defining an effective political strategy that encourages a shift in freight transport modes from road to rail, in accordance with the White Paper [16]. The following sections analyse each level that influences freight transport policies in the Brenner corridor, from macro scale (European Union) to local scale (Euroregion and Autonomous Province of Bolzano).

\subsection{The European Union}

The major challenges posed by the EU related to freight transport concern the reduction of greenhouse gas (GHG) emissions [20] and dependence on oil, as well as the creation of infrastructures capable of connecting the various countries, with the aim of developing a single market from an environmental, social and economic perspective. In the White Paper [16], the European Commission insists on introducing and promoting cleaner and more efficient engines and fuel for freight transport over short-to-medium distances (less than $300 \mathrm{~km}$ ), such as liquefied petroleum gas. For longer distances, as mentioned above, the aim is to transfer $30 \%$ of road freight transport to less polluting transport modes by 2030 , and $50 \%$ by 2050 (objective no. 3). To achieve this objective, the EU has to unify single transport markets and support the internal rail network. By 2030, the multimodal TEN-T network is expected to be fully operational throughout Europe (objective no. 5). Objective no. 10 intends to make the private sector responsible according to the "polluter pays" and "user pays" principles. Revenues must be used to develop strategic infrastructure for sustainable transport. To achieve these objectives, the EU is acting on two different modes - road and rail through various legislative instruments (Table 2).

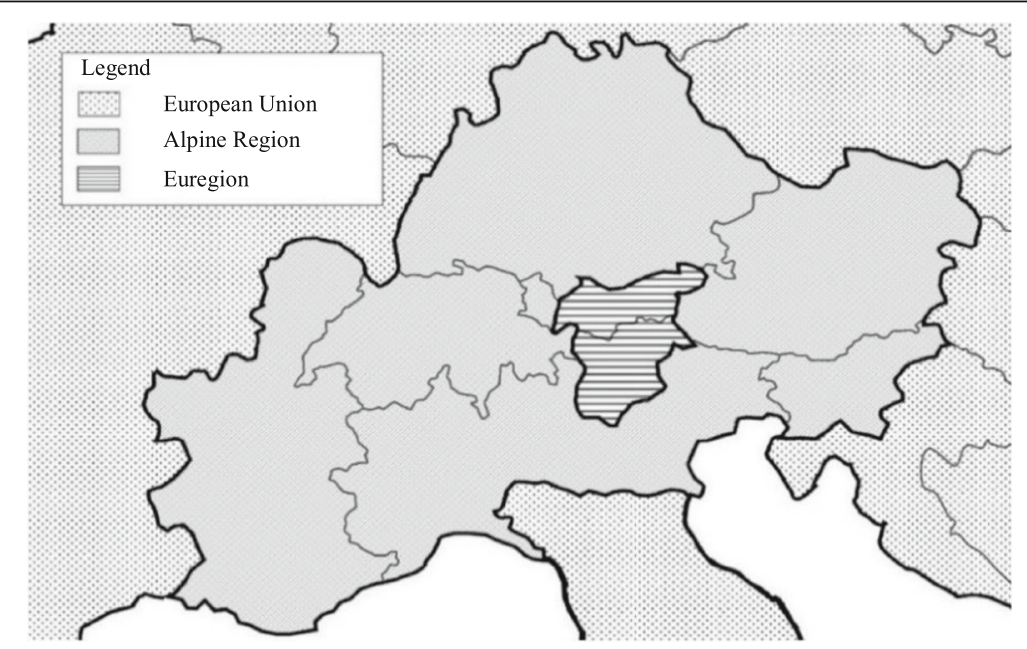

Fig. 2 The three geopolitical levels of the Brenner corridor 
Table 2 EU legislative documents concerning the regulation of road and rail freight transport [40]

\begin{tabular}{ll}
\hline Mode & Legislative documents \\
\hline Road & $\begin{array}{l}\text { Common rules for access to the international road haulage } \\
\text { market (Regulation no. 1072/2009) }\end{array}$
\end{tabular}

Goods: towards a safer and more competitive high-quality road transport system (COM (2000) 364)

Taxation on HGVs transporting freight by road: Eurovignette Directive (Directive 2011/76/EU)

Rail State aid to railway companies (Community Guidelines on State Aid for Railway Undertakings)

A European rail network for competitive freight (Regulation (EU) no. 913/2010)

Freight transport logistics action plan (COM (2007) 607 def.)

Establishing a single European railway area (Directive 2012/34/EU).

\section{Description}

Definition of the common rules to access the international and cabotage markets to promote fair and non-discriminatory competition and the conditions with which non-resident carriers must comply to provide services in the EU (EU driving licence and driver certification).

Reinforcement of the conditions that help to achieve fair competition. Measures have to achieve the following objectives: (1) to develop legislation on the organisation of working hours; (2) to balance working conditions; (3) to improve road transport monitoring; (4) to increase professional training.

Harmonisation of the conditions under which national authorities can apply taxes, tolls and user charges for road freight transport. The threshold for the application of charges was lowered from $12 \mathrm{t}$ to $3.5 \mathrm{t}$. Charges can also be applied to motorways, bridges, tunnels and mountain passes, but cannot discriminate on the basis of the carrier's nationality. National authorities may apply other taxes in case of specific circumstances, such as registration, abnormal loads or congestion.

These guidelines clarify the rules established in the EU treaties on public funding for railway companies and provide guidance on the compatibility of state aid to railway companies with EU treaties. Support measures are divided into: (1) support through infrastructure financing; (2) aid for the purchase and renewal of rolling stock; (3) writing off of debts by States, in order to financially restructure railway undertakings; (4) aid for the restructuring of railway undertakings; (5) aid for the coordination of transport; (6) guarantees granted by the State to railway companies.

This regulation establishes the rules related to the construction and organisation of international railway network. Establishment of 9 relevant freight corridors that the EU countries concerned need to make operational. Establishment of an executive committee and a management committee. Establishment of a single office, which will make the decisions on the railway routes and stock capacity requests for international freight trains.

The action plan contains short- and medium-term measures to improve the efficiency and sustainability of freight transport. It includes use of ICT; training of qualified staff; simplification of administrative requirements; reviewing the European legislation in terms of weight and size; transport passes; urban planning measures to accommodate freight transport.

The contents of the first package concern the separation of infrastructure management and transport activities, railway undertaking licences and infrastructure rates. The conditions for accessing the market, services and rules regarding the collection of charges are also defined.

\subsection{The alpine region}

The Brenner corridor is part of the Alpine area, one of the largest continuous natural areas in Europe. The Alpine Convention, set in 1991, defines the general obligations of each State and the lines of legal, scientific, economic and technical collaboration, with the ultimate aim of preserving and protecting this important region [21]. Members stipulates general transport obligations, which are included in the Transport Protocol [22]. The contracting States commit to take environmental, social and economic needs into consideration, with the ultimate goal of adopting a policy aimed at reducing the impacts generated by inter-Alpine and transalpine transport, by managing it in a co-ordinated, rational and safe manner. As regards rail, the States intend to optimise the management of the existing assets, modernising infrastructure and defining a series of measures to transfer long-distance freight transport to rail. In line with European policies, great emphasis is put on the importance of properly harmonising charges for the use of infrastructure between the various Alpine corridors.

The "Zurich Process" [23] is a communication platform between the Alpine countries (France, Italy, Germany, Austria, Switzerland, Slovenia and the Principality of Liechtenstein), intended to reinforce road safety, to harmonise technical standards for motorway freight transport and to optimise the transfer of freight traffic to rail. The "Zurich Process" consists of a Steering Committee, which has been tasked with developing and guaranteeing a policy to safeguard the Alpine region, and five working groups to develop solutions in the following areas: traffic management systems; accident management; data collection and assessment; development of environmental indicators, and tunnel safety.

The EUSALP (EU Strategy for the Alpine Region) [24] was developed in 2013 between 48 regions and autonomous provinces belonging to the seven alpine countries. Unlike the Alpine Convention, the decisions of which 
have legal value, the EUSALP provides policy tools and strategies to improve cooperation between the various Alpine states, without being legally binding. The works carried out by the Alpine Macroregion are divided into Action Groups (AGs). The AG4, led by the Tyrol-South Tyrol-Trentino Euroregion is dedicated to the intermodality and interoperability of freight and passenger transport. The specific objectives of the AG4 can be summarised into three points: (i) promoting the intermodality and interoperability of freight and passenger transport; (ii) supporting the modal shift from road to rail, and (iii) developing cooperation and integration between the various structures and bodies in the transport industry. A series of actions has already been implemented and developed by the countries involved in the project - several of which are discussed in section 4 .

Finally, a mention to relevant transalpine projects have to be made. "iMONITRAF!" [25] is an Alpine Space project developed to monitor traffic in the Alps and to propose common solutions on a regional level that would reduce the pressure of transalpine traffic. The project, which is the follow-up of the project "MONITRAF" (Monitoring of Road Traffic-related Effects in Alpine Space and Common Measures), was funded within the European Alpine Space 2007-2013 programme and subsequently made independent on a regional level through the creation of a Coordination Point. For some years, iMONITRAF! has specifically focussed on developing the Toll+ measure, with the aim of improving the internalisation of external costs and harmonising the existing pricing systems between the various countries. Another European project consistent with the EUSALP principles and the White Paper on Transport [16] is AlpInnoCT (Alpine Innovation for Combined Transport). Its main purpose is to increase the efficiency and productivity of combined transport (CT) through improvements to processes, the cooperation of CT networks, and the integration of innovative approaches to encourage the shift from road to rail [26].

All initiatives presented in this section work on common aims, which are coherent with the purposes expressed at the continental level.

\subsection{The Tyrol-South Tyrol-Trentino Euroregion}

Being part of different States (Austria and Italy), Tyrol, Trentino and South Tyrol differ also in the adoption of policies and measures in order to achieve the modal shift. Tyrol decided to introduce: toll diversification based on the classification of European emissions [27]; a sector-based traffic ban on a stretch of the Inntal A12 motorway; a ban on night-time traffic for heavy vehicles; a traffic ban on highly polluting vehicles; and lastly, speed limits according to the law on the protection from emissions on certain stretches of Tyrol motorway network [28]. South Tyrol and Trentino have acted differently: they have promoted combined transport by granting contributions to public and private entities [29] rather than discouraging road freight transport with taxes and bans. Furthermore, investments for the intermodal centre of Trento, which provides a RoLa service with Wörgl, are guaranteed.

This diversity in interventions still leads to difficulties in managing the flow of goods. The Tyrol-South TyrolTrentino Euroregion was founded to improve coordination between the three administrations, also referring to transport issues. The Euroregion is committed to transforming the aforementioned strategies into a series of specific measures. The first step is to define "an agreed common strategy for the gradual transfer of freight traffic from road to rail" [30, 31]. In 2015, the EGTC (European Grouping of Territorial Cooperation) encouraged the development of a study on the Toll+ based on the Eurovignette Directive, in line with both the indications deriving from iMONITRAF! [25] and the European policies. The intention is to use the "Plus" component to introduce concrete measures to reduce air and noise pollution. The rolling highway (RoLa) is indicated as a fundamental integrative solution. In 2016, the three regions confirmed their support to the application of the Eurovignette on the Brenner highway; the implementation of the Toll+ system; the modification of the New Highway Code to regulate speed; the support for the "Green Brenner corridor"1 strategy; and the request to Ministries regarding the possibility of introducing transit bans along the Brenner axis for trains with unsuitable levels of train noise.

The most recent political document is the "Strategia dell'Euregio per il trasferimento del traffico dalla strada alla rotaia: obiettivi strategici per una politica dei trasporti comune, coerente e sostenibile lungo l'asse del Brennero" [19]. It affirms support for a rail-oriented freight transport policy. The commitments indicate an even more ambitious objective: a balance in transport modes by 2027 and a reversal of the current values by 2035 ( $29 \%$ by road and $71 \%$ by rail). Alongside their respective ministries, the three regions will also request compatibility between railway regulations and the removal of infrastructural obstacles, which, on a national level and in comparison to other European States, limit freight transport. The most important action proposed in this resolution is the increase in motorway tolls, an action supported from the renewed management of the A22 motorway operator. The new fees must be in line with those planned for the other Alpine corridors - currently, they are one of the lowest [25]. An electronic payment system is planned to be introduced, as well as a series of interventions to prevent alternative routes from being used to avoid the toll. Several steps have still to be taken, 
in order to achieve an effective harmonisation of the policies and instruments put in place by the various $\mathrm{Al}$ pine regions, but the establishment of the Euroregion has significantly facilitated the operations of international and interregional coordination.

The three policy levels presented in this section are coherent and confirm the importance of a multi-level approach that aims at optimizing the different transport modes, by encouraging the use of railway, both for freight and passenger transport. This objective can be supported by the introduction of specific measures, which are the focus of the next section.

\section{Measures for achieving the modal shift}

This paragraph describes the measures capable of promoting the modal shift from road to rail. Firstly, it is necessary to investigate the factors influencing the modal choice of shippers and freight forwarders, as well as the specific pros and cons of each transport mode [32]. If implemented in a coordinated manner on a trans-regional level, the analysis of the strengths and weaknesses of rail and road transport contributes to the development of a suitable strategy to support the desired modal diversion. The choice of a specific transport mode is determined by preferences expressed by the two key players involved at the beginning of the process - the carrier and the shipper. However, despite the latter being the practical organiser of the transport, its decision is strongly influenced by the former's preference, who makes the choice according to the customer's economic, financial and technical requirements. The factors influencing the modal choice can be grouped into two categories: "micro" and "macro".

The micro factors represent the single elements capable of influencing the individual choice of the shippers [7]: (i) the shipping agent itself (railway accessibility, practices and customs of the decision makers); (ii) the shipped goods (size and type, density, value per unit of product, perishability, packaging features, etc.); (iii) the carrier (cost of shipment, delivery time, infrastructure capacity, service reliability, degree of security, service flexibility and frequency, availability of special equipment, customer service quality, transportation procedures, level of environmental sustainability, etc.); (iv) the shipment (distance travelled, train capacity, etc.).

The macro level factors influence the shippers' choice in the medium and long term. A close relation was found between the economic growth (expressed as GDP) and freight volumes [33]. Economic growth does not have the same impact on road and rail freight transport. European manufacturing processes have changed drastically in recent years and freight transport has attempted to adapt to new market demands. On the one hand, many European countries are experiencing a decline in the quantity and size of the main industries and a dispersion of the manufacturing process (de-industrialisation of the region). On the other hand, growth in e-commerce is generating a logistical fragmentation of distribution journeys and, as a result, new demand for light vehicles in urban and periurban areas. It derives the need for transport of smaller volumes at a higher frequency [33]. Road transport is more competitive than rail transport when it comes to meeting this demand - and more attractive to a shipper in terms of cost and time. However, the point of view of shippers is important, but not exclusive. An element that influences the EU transport policy is the environmental protection and the sustainability of vehicles, which favour rail over road transport (see section 3). This element not included in expenses incurred by the user, unless marginally - is becoming important in terms of planning, through a progressive internalisation of such values. Although the first two macroeconomic factors favour the road transport choice, the numerous incentives and subsidies provided by the EU to railways and intermodality drive the shipping agent towards choosing a lower impact vehicle.

The instruments that can directly or indirectly influence the modal choice by encouraging or discouraging a specific behaviour can be influenced through the application of two mechanisms: making the undesirable options less attractive (push measures) or increasing the attractiveness of the alternatives (pull measures). In the passenger transport sector, these mechanisms are generally used to discourage the use of private cars and increase individuals' inclination to public and alternative transport. Referring to freight transport, the two groups can be defined as follows:

- Push measures: imposed on road freight transport with the aim of discouraging its use, these measures include financial instruments (e.g. taxes, charges and tolls) and regulatory constraints (e.g. orders and bans).

- Pull measures: increasing the attractiveness of rail freight transport over other modes, they include very different initiatives, from financial incentives and increasing service reliability, to physically expanding the railway system and reducing shipping costs.

These measures can be arranged into three closely interconnected groups: (i) measures affecting the infrastructures (railway network, terminals, etc.); (ii) measures affecting service management (speed, times, costs, flexibility, intermodality, interoperability, etc.); and (iii) regulatory measures governing the entire system according to individual influence mechanisms (Fig. 3). The next sections take into consideration the measures applied 


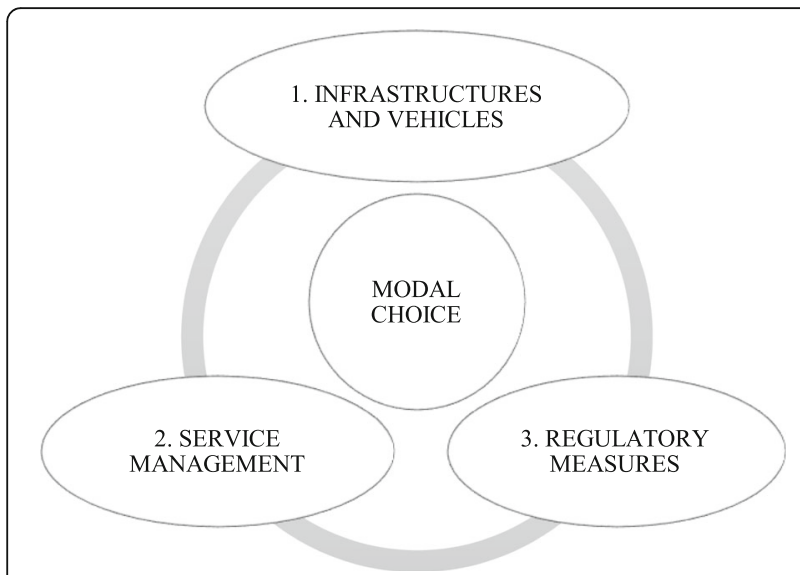

Fig. 3 Macro categories of measures that influence the users' modal choice

and applicable to the Alpine arc to achieve the objectives proposed by the EU, the Alpine Convention, the EUSALP macro strategy and the Tyrol-South TyrolTrentino Euroregion. The first two groups - infrastructure and vehicles, and service management - contain pull measures alone, aiming to make the freight transport system more appealing and competitive by increasing its functional and organisational attractiveness. The third group - regulatory measures - includes all actions to encourage the use of rail transport and discourage the use of road transport. For each group, Tables 3, 4 and 5 show the selected measures, followed by a brief description and States in which they have been applied.

\subsection{Infrastructure and vehicles}

Rail transport is economically convenient over long distances $(>500 \mathrm{~km})$ and with substantial volumes. It can compete with road transport when it meets users' needs with a flexible, intermodal and adequately equipped network characterised by efficiently localised intermodal terminals. To this aim, two parallel actions can be developed: (i) investing in the railway network, the standardisation of transport vehicles, terminals, platforms, etc.; and (ii) developing an efficient hinterland intermodal network. These two lines of action (Table 3) intend to create a single, intermodal and interoperable system. In the EU, this objective is far from been realized: differently from a motorway infrastructure extensively developed, railway infrastructure is not evenly distributed, and many countries still lack a high-speed connection. Along the Brenner corridor, the construction of new railway infrastructures includes the realization of the Brenner Base Tunnel (BBT) between Innsbruck (AT) and Fortezza (IT), as well as the forecasted construction of the Southern access route between Verona and Fortezza. Regarding the renovation of the existing infrastructure, Italy has also allocated relevant funds in safety projects and technological modernization of the existing line. The projects of renovation regard also the intermodal terminals, such as the enlargement of Roncafort (Trento) and Quadrante Europa (Verona) terminals. Currently, no new projects of intermodal terminals are planned. Finally, regarding the common standards, the European Railway Traffic Management System (ERTMS) is expected to be introduced along the Brenner corridor by 2021.

\subsection{Service management}

The effective management of the service aims to consolidate the reliability of the European railway system. A recent study [7] showed that one of the priorities of the EU Commission and Member States is to assist train and infrastructure managers in improving the reliability, frequency, and flexibility of rail freight transport in an attempt to reduce times and costs. For example, using ITS (Intelligent Transport Systems) can optimise the efficiency of freight transport [34]. The problem lies not only in reinforcing the road and intermodal terminal infrastructures, but also in managing the service as a

Table 3 List of measures belonging to the "Infrastructure and vehicles" group

\begin{tabular}{|c|c|c|}
\hline \multicolumn{3}{|l|}{ INFRASTRUCTURE AND VEHICLES } \\
\hline Measure & Description & Field of application \\
\hline $\begin{array}{l}\text { 1. Renovation of existing } \\
\text { infrastructure }\end{array}$ & $\begin{array}{l}\text { Homogenisation of infrastructural elements (e.g. development of a single electrification } \\
\text { system and standardisation of railway gauges) and maintenance of the existing network. }\end{array}$ & $\mathrm{AT}, \mathrm{CH}, \mathrm{DE}, \mathrm{IT}, \mathrm{FR}, \mathrm{SL}$ \\
\hline $\begin{array}{l}\text { 2. Renovation of intermodal } \\
\text { terminals }\end{array}$ & $\begin{array}{l}\text { Increase in the structural efficiency of intermodal terminals. Promotion of specific projects to } \\
\text { upgrade intermodal hubs, adapt equipment, expansion, construction and/or modification of } \\
\text { components (bridges, tunnels, etc.) to improve access to the terminal area. In this sense, } \\
\text { reliable hinterland connections are a fundamental aspect. }\end{array}$ & AT, CH, DE, IT, FR, SL \\
\hline $\begin{array}{l}\text { 3. Construction of new railway } \\
\text { infrastructure }\end{array}$ & $\begin{array}{l}\text { Construction of new infrastructure connecting intermodal ports and terminals. Investments } \\
\text { in the construction of new railway infrastructure are based on the TEN-T strategy. }\end{array}$ & AT, CH, DE, IT, FR, SL \\
\hline $\begin{array}{l}\text { 4. Construction of new } \\
\text { intermodal terminals }\end{array}$ & $\begin{array}{l}\text { Construction of new intermodal terminals suitably located along railway axes relevant to the } \\
\text { TEN-T network. As regards upgrading (measure 2), the construction of a new intermodal } \\
\text { terminal is much rarer. }\end{array}$ & AT, CH, DE, IT, FR, SL \\
\hline 5. EU common standards & $\begin{array}{l}\text { Adoption of common standards to avoid bottlenecks and make rail transport more } \\
\text { competitive. }\end{array}$ & - \\
\hline
\end{tabular}


Table 4 List of measures belonging to the "Service Management" group

\begin{tabular}{|c|c|c|}
\hline \multicolumn{3}{|l|}{ SERVICE MANAGEMENT } \\
\hline Measure & Description & $\begin{array}{l}\text { Field of } \\
\text { application }\end{array}$ \\
\hline $\begin{array}{l}\text { 1. Measures to simplify and streamline management } \\
\text { procedures and administrative controls }\end{array}$ & $\begin{array}{l}\text { Measures acting on an administrative level regarding actions that involve access } \\
\text { to terminals, transparency and the fairness of the intermodal structure and its } \\
\text { management, in order to maintain non-discriminatory competition between the } \\
\text { various transport operators (e.g. electronic monitoring of vehicles, railway } \\
\text { custom passes, etc.) }\end{array}$ & $\begin{array}{l}\text { AT, CH, DE, } \\
\text { IT, FR, SL }\end{array}$ \\
\hline $\begin{array}{l}\text { 2. Improvement of operational accessibility to } \\
\text { intermodal terminals: non-stop timetable }\end{array}$ & $\begin{array}{l}\text { Increase in the opening times of the intermodal hubs to } 7 \text { days a week and } \\
24 \mathrm{~h} \text { a day, in order to help transport operators and improve carrier services. } \\
\text { This measure has a significant impact on the efficiency of the intermodal system } \\
\text { in terms of cost and time. }\end{array}$ & $\begin{array}{l}\text { Only few } \\
\text { terminals }\end{array}$ \\
\hline $\begin{array}{l}\text { 3. ITS measures to improve combined transport } \\
\text { operations }\end{array}$ & $\begin{array}{l}\text { Use of technology capable of increasing the efficiency of rail and intermodal } \\
\text { freight transport. These instruments vary from ITS (Intelligent Transport System) } \\
\text { to apps and software designed for the coordinated and harmonised } \\
\text { management of the service. Real-time data is an important component of this } \\
\text { group. }\end{array}$ & $\begin{array}{l}\text { AT, CH, DE, } \\
\text { IT, FR, SL }\end{array}$ \\
\hline 4. Research projects to increase the efficiency & $\begin{array}{l}\text { Development of research projects that can contribute to make the system more } \\
\text { efficient, safe and sustainable. These projects must have practical effects that } \\
\text { bring tangible benefits. }\end{array}$ & $\begin{array}{l}\text { AT, } C H, D E, \\
\text { IT, FR, SL }\end{array}$ \\
\hline 5. Interoperability of the railway system & $\begin{array}{l}\text { Implementation of the technical measures and management rules shared by the } \\
\text { Member States, defined technical specifications of interoperability (TSI), in order } \\
\text { to develop a single market. }\end{array}$ & $\begin{array}{l}\text { AT, CH, DE, } \\
\text { IT, FR, SL }\end{array}$ \\
\hline 6. Freedom of access to the railway network & $\begin{array}{l}\text { Opening the railway network to third parties with respect to infrastructure } \\
\text { managers, in order to create a single market in the freight and passenger } \\
\text { transport sector. }\end{array}$ & $\begin{array}{l}\text { AT, FR, DE, } \\
\mathrm{IT}, \mathrm{SL}\end{array}$ \\
\hline
\end{tabular}

whole. Table 4 includes the main measures that can contribute in obtaining this objective. Not all measures reported are implemented along the Brenner corridor. For instance, the improvement of operational accessibility to terminals still regards only few terminals in other contexts and ITS development of intermodal terminals is heterogenic (more developed in Quadrante Europa, in its initial phase in Roncafort). Other measures (Research projects, Interoperability and Freedom of access to the railway network), are carried out by all countries along the Brenner corridor. In Italy, for instance, the Autonomous Province of Bolzano is participating in several EU projects, such as iMonitraf!, Smartlogi and AlpInnoCT to improve the efficiency of freight transport in the Alpine area. Other projects - such as Transitects, Susfreight, Alpcheck, Ursa Major II e Ursa Major neo have been developed in the previous years. Finally, interoperability and freedom of access to the railway network are fundamental conditions set by European Union to all Member States. The Brenner Corridor Platform (BCP) has been set up to guarantee an integrated approach for the entire line between Munich and Verona.

\subsection{Regulatory measures}

Regulatory measures can directly influence the user's choice by encouraging or discouraging a specific behaviour through the application of push and pull measures. In this case, no action is taken on the physical structure of the system (infrastructure, terminals and vehicles), nor on service management, but rather on the shipping agent's choice, through the implementation of limits, subsidies, exemptions, taxes, obligations and bans (Table 5). Along the Brenner corridor, the condition varies according to the single countries. Some measures have been introduced both in Austria and in Italy - some of them are applied differently, according to the national rules (e.g., traffic ban on specific days according to the national holidays, speed limits, financial subsidies for combined transport). In Austria, for instance, the maximum weight allowed for trucks is $40 \mathrm{t}$ ( $44 \mathrm{t}$ for those providing a CT service), while in Italy the maximum weight is $44 \mathrm{t}$, without any distinction. Other measures have been introduced in one country, such as the Austrian sectoral driving ban, the differentiation of the tolls according to the Euro classes and the night driving ban on Euro 0-V trucks.

\section{External costs along the Brenner corridor: A calculation of potential savings}

This paragraph focuses on the study of the external costs resulting from freight transport and on the environmental benefit that can be generated from the achievement of the objectives proposed by the resolution proposed by Tyrol-South Tyrol-Trentino Euroregion [19]. To calculate this benefit, the current external costs generated by freight transport along the Brenner corridor (Phase 02015) have to be evaluated. A calculation is then made of the external costs generated by freight transport in 
Table $\mathbf{5}$ List of measures belonging to the "Regulatory Measures" group

\begin{tabular}{|c|c|c|}
\hline \multicolumn{3}{|l|}{ REGULATORY MEASURES } \\
\hline Measure & Description & $\begin{array}{l}\text { Field of } \\
\text { application }\end{array}$ \\
\hline \multicolumn{3}{|l|}{ PUSH MEASURES } \\
\hline 1. Weight and size limits & $\begin{array}{l}\text { Weight and size limits on heavy vehicles in order to discourage the use of } \\
\text { road freight transport in favour of rail, which is exempt from these } \\
\text { constraints. }\end{array}$ & $\begin{array}{l}\text { AT, CH, DE, } \\
\text { FR, IT, SL }\end{array}$ \\
\hline 2. Traffic ban on specific days/times/seasons & $\begin{array}{l}\text { Traffic ban on all freight transport vehicles exceeding } 7.5 \mathrm{t} \text { during public } \\
\text { holidays and/or specific periods of the year and/or days of the week and/or } \\
\text { specific times of day. }\end{array}$ & $\begin{array}{l}\text { AT, CH, DE, } \\
\text { FR, IT, SL }\end{array}$ \\
\hline $\begin{array}{l}\text { 3. Traffic ban/limit based on European emissions } \\
\text { classifications }\end{array}$ & $\begin{array}{l}\text { Traffic ban based on the EU classification of emissions in certain stretches } \\
\text { that are fragile from an environmental point of view (e.g. tunnels, highly } \\
\text { polluted urban areas, Low Emissions Corridors/Zones). }\end{array}$ & $\begin{array}{l}\text { AT, } \mathrm{CH}, \mathrm{IT} \\
\mathrm{FR}\end{array}$ \\
\hline 4. Sector-based traffic ban & $\begin{array}{l}\text { Sector-based traffic ban on certain categories of goods and vehicles imposed } \\
\text { nationally by individual Member States. }\end{array}$ & AT \\
\hline 5. Speed limits and overtaking & $\begin{array}{l}\text { Permanent speed limits on certain stretches of the motorway route and } \\
\text { overtaking ban. This measure discourages road freight transport, given that it } \\
\text { increases travel time compared with rail freight transport. }\end{array}$ & $\begin{array}{l}\text { AT, CH, DE, } \\
\text { IT, FR, SL }\end{array}$ \\
\hline 6. Differentiation of tools/user charges - external cost & $\begin{array}{l}\text { Differentiation of toll rates/user charges on specific motorway stretches } \\
\text { where vehicles generate higher negative external effects such as air } \\
\text { pollution, noise and congestion. }\end{array}$ & $\mathrm{AT}, \mathrm{CH}$ \\
\hline $\begin{array}{l}\text { 7. Differentiation of tools/user charges - infrastructure } \\
\text { cost }\end{array}$ & $\begin{array}{l}\text { Application of a toll surcharge for using the infrastructure on a specific } \\
\text { motorway stretch that has higher construction and maintenance costs than } \\
\text { normal infrastructure (e.g. mountainous stretches). }\end{array}$ & $\begin{array}{l}\text { AT, } C H, D E \\
\text { IT, FR, SL }\end{array}$ \\
\hline $\begin{array}{l}\text { 8. Differentiation of vehicle taxes for HGVs according } \\
\text { to EU emission classifications }\end{array}$ & $\begin{array}{l}\text { Differentiation of vehicle taxes or application of exemptions and reductions } \\
\text { for heavy vehicles based on weight, number of axles and EU classification of } \\
\text { emissions. }\end{array}$ & $\begin{array}{l}\text { AT, CH, DE, } \\
\text { IT, FR, SL }\end{array}$ \\
\hline \multicolumn{3}{|l|}{ PULL MEASURES } \\
\hline $\begin{array}{l}\text { 9. Financial subsidies for combined and intermodal } \\
\text { freight transport }\end{array}$ & $\begin{array}{l}\text { Financial subsidies intended for intermodal or trans-shipment rail transport } \\
\text { services and for combined transport operators. }\end{array}$ & $\begin{array}{l}\text { AT, CH, DE, } \\
\text { FR, IT, SL }\end{array}$ \\
\hline 10. Exemption from load and size limits & $\begin{array}{l}\text { Exemptions from load and size limits for heavy vehicles involved in } \\
\text { intermodal freight transport in order to promote transport intermodality. }\end{array}$ & $\begin{array}{l}\text { AT, } \mathrm{CH}, \mathrm{DE} \\
\text { IT, FR, SL }\end{array}$ \\
\hline $\begin{array}{l}\text { 11. Exemption from traffic bans on specific days/times/ } \\
\text { seasons }\end{array}$ & $\begin{array}{l}\text { Exemption from traffic bans on specific days/times/seasons for heavy vehicles } \\
\text { involved in intermodal freight transport. }\end{array}$ & $A T, D E, I T, S L$ \\
\hline 12. Exemption from toll payments & Exemption from paying higher unit tolls for intermodal freight transport. & SL \\
\hline 13. Reduced stamp duty or tolls & Reduced vehicle taxes for all heavy vehicles involved in combined transport. & $\mathrm{IT}, \mathrm{SL}$ \\
\hline
\end{tabular}

two different scenarios. In Scenario 1, the current modal split does not change (29\% rail - 71\% road); in Scenario 2 the external costs are calculated if a balance in the modal split is achieved (50\% rail-50\% road; Phase 12027 ) and if the current split is reversed (71\% rail - 29\% road; Phase 2-2035). By subtracting the external costs generated by the new modal split (Phase 1 and Phase 2) in Scenario 2 from those calculated in Scenario 1, the economic saving generated by the Euregion resolution can be obtained.

\subsection{Starting data for calculating external costs}

According to [35], the selection of the external costs along the Brenner corridor includes local pollution, global pollution, noise pollution, accidents and congestion. In that study, the total external costs are differentiated based on the tonne of goods (net or gross) transported by two different vehicle types and one train type. In this article, only the individual net tonne transported by vehicle type 1 (articulated lorry, with a total mass of $40 \mathrm{t}$ ) and by train are considered, since the focus is on transnational transport and the vast majority of vehicles performing this kind of service belong to these vehicle types. The characteristics of each vehicle are shown in Table 6.

For both scenarios, three reference years have been selected: 2015 (the year data were collected from the iMONITRAF! project [25]), 2027 and 2035 (the time limits within which the Euroregion objectives must be achieved). The calculation of external costs can be summarised into two separate phases: firstly, quantifying the external effects considered; secondly, expressing them in economic terms by multiplying the values by the external unit costs of reference. Regarding this last aspect, this paper adopts in most cases the values provided by Ricardo-AEA [4]. This manual, 
Table 6 Starting data for calculating external costs along the Brenner corridor [35]

\begin{tabular}{|c|c|c|c|c|}
\hline \multirow{2}{*}{$\overline{\text { Data }}$} & \multirow{2}{*}{ Features } & \multicolumn{3}{|l|}{ Data selected in the study } \\
\hline & & Vehicle type 1 & Vehicle type 2 & Train \\
\hline \multirow[t]{8}{*}{ Vehicle } & Vehicle model & Articulated truck & Rigid truck & Train with 2 locomotives \\
\hline & Fuel & Diesel & Diesel & Electric traction \\
\hline & $\begin{array}{l}\text { European emissions } \\
\text { classification }\end{array}$ & Euro 0 - Euro 6 & Euro 0 - Euro 6 & - \\
\hline & \multirow[t]{4}{*}{ Load } & Total mass: $40 \mathrm{t}$ & Total mass: $26-28 \mathrm{t}$ & Gross train weight: $1200 \mathrm{t}$ \\
\hline & & Tare: $8 \mathrm{t}$ & Tare: $7.5 \mathrm{t}$ & Gross freight weight: $1020 \mathrm{t}$ \\
\hline & & Load capacity: 32 t & Load capacity: 20 t & Net freight weight: 597 t \\
\hline & & Goods transported: $16 \mathrm{t}$ & Goods transported: $10 \mathrm{t}$ & \\
\hline & $\begin{array}{l}\text { Type of emissions } \\
\text { considered }\end{array}$ & Hot emissions & Hot emissions & - \\
\hline \multirow[t]{6}{*}{ Infrastructure } & Type & Motorway & Motorway & Railway \\
\hline & Maximum travel speed & $80 \mathrm{~km} / \mathrm{h}$ & $80 \mathrm{~km} / \mathrm{h}$ & $100 \mathrm{~km} / \mathrm{h}$ \\
\hline & \multirow[t]{2}{*}{ Slope } & Min: $-4 \%$ & Min: $-4 \%$ & - \\
\hline & & Max: $+4 \%$ & Max: $+4 \%$ & \\
\hline & Geographical context & Rural & Rural & Rural \\
\hline & Congestion level & $\begin{array}{l}\text { Free flow, with temporary } \\
\text { exception between } \\
\text { Bressanone and Vipiteno }\end{array}$ & $\begin{array}{l}\text { Free flow, with temporary exception } \\
\text { between Bressanone and Vipiteno }\end{array}$ & - \\
\hline Emission models & Macro scale & HBEFA & HBEFA & Not used (TTW phase) \\
\hline
\end{tabular}

commissioned by the EU, is used as a reference document in order to provide assessments in accordance with the long-term objectives set on a continental level. $^{2}$ The process of quantifying the external effects considered in the study is summarised below. ${ }^{3}$

\subsubsection{Local air pollution}

By using the unit values provided by HBEFA [36] based on the slope, infrastructure features and specific traffic conditions of the A22 (Table 6), it is possible to estimate the total emissions of local pollutants $\left(\mathrm{CO}, \mathrm{SO}_{2}, \mathrm{NO}_{2}, \mathrm{~Pb}\right.$ and $\left.\mathrm{PM}_{\mathrm{x}}\right)$ produced by heavy vehicles in the South Tyrolean stretch of the Brenner corridor in direction north-south and south-north. For rail, air pollution is zero, since the study only considers the Tank-to-Wheel (TTW) phase and all trains operating along the Brenner line are powered by electricity.

\subsubsection{Global air pollution}

As for the external effects mentioned above, the HBEFA unit values [36] pertaining to the unit emissions of the main global pollutants $\left(\mathrm{CO}_{2}, \mathrm{CH}_{4}\right.$ and $\mathrm{N}_{2} \mathrm{O}$, expressed also in aggregated terms as $\mathrm{CO}_{2 \mathrm{eq}}$ ) emitted by the standard road freight transport vehicle were used. For rail, global air pollution was again zero.

\subsubsection{Noise pollution}

To quantify the highway component, a synthetic unitary estimate provided on a national level by RicardoAEA [4] was used. As regards rail, reference is made to the unit noise produced by an individual freight train, influenced by the average traffic density, the time of day and the territorial context of reference (urban, suburban or rural).

\subsubsection{Accidents}

For road transport, the number of accidents that occurred along the Brenner motorway and involved at least one heavy vehicle (exceeding $7.5 \mathrm{t}$ ) was considered. This figure is broken down according to the number of accidents that caused injuries, deaths or accidents with damage to property. Each group of accidents is divided by the number of annual $\mathrm{km}$ travelled by heavy vehicles in order to obtain the unit accident rate, which is then multiplied by the distance travelled by a standard vehicle on the motorway stretch. For rail transport, in the absence of more accurate data, we consider a simplified assessment produced by Ricardo-AEA [4], which quantifies the impacts on the national average, according to the transport mode taken into account.

\subsubsection{Congestion}

The average annual condition of the A22 motorway is free-flow traffic, with a critical section between the 
Bressanone and Brenner tollbooths. In this case, a precautionary congestion condition of $15 \mathrm{~h}$ per week is considered. To calculate the railway congestion, we assume the maximum capacity of the Brenner railway line equal to 200 trains/day, lower than actual values. Thus, this externality in 2015 is considered equal to zero.

\subsection{Two traffic scenarios along the Brenner corridor}

The above external effects are assessed in two different scenarios (called "Status quo" and "Euroregion"), constructed using historical traffic data and the modal split recorded along the Brenner corridor from 1985 to 2015 (the year of this study, "year 0") and projected to 2035 using a trend model. The linear trend model applied uses the method of least squares, a standard approach in regression analysis, to calculate the future quantities moved. The total volumes of goods transported are the same, but the modal split is different. Three dates play a central role, in accordance with the aforementioned Euroregion Resolution [19]: 2015, considered the year of reference for both scenarios, 2027 and 2035.

Before analysing the single scenarios, the external unit costs referring to a net tonne transported by vehicle type 1 and by train are calculated in Table 7 . Phase 0 , which is common to both scenarios, represents the status described by Cavallaro [34], referred to the year 2015 and based on data provided by iMONITRAF! [18]. The modal share of freight transport in the Brenner corridor between rail and road is $29 \%$ and $71 \%$ respectively, corresponding to $12.6 \mathrm{Mt}$. of goods transported by rail and 31.2 Mt. by road (Section 2; [18]). The external cost generated by transporting a tonne by road amounts to $€ 1.583 / t_{\text {net }}$, whilst for rail, a value of $€ 0.006 / t_{\text {net }}$ is estimated (Table 7). These unit costs and the quantity of goods transported result in total external costs equal to $€ 49.3 \mathrm{M}$ for road and $€ 81,391$ for rail $(0.16 \%)$. For

Table 7 External costs along the South Tyrolean stretch of the Brenner corridor

\begin{tabular}{|c|c|c|c|c|c|c|c|c|c|}
\hline \multicolumn{10}{|c|}{ External costs along the South Tyrolean stretch of the Brenner corridor $\left(€_{\text {cent }} / t_{\text {net }}\right)$} \\
\hline & & \multirow{2}{*}{\multicolumn{2}{|c|}{ Specifications }} & \multicolumn{2}{|l|}{ Phase 0-2015 } & \multicolumn{2}{|l|}{ Phase 1-2027 } & \multicolumn{2}{|l|}{ Phase 2-2035 } \\
\hline \multicolumn{2}{|c|}{ External effects } & & & Vehicle type 1 & Train & Vehicle type 1 & Train & Vehicle type 1 & Train \\
\hline$a$ & Local pollution & \multicolumn{2}{|l|}{ Euro 1} & 85.46 & - & - & - & - & - \\
\hline & & \multicolumn{2}{|l|}{ Euro 2} & 85.02 & - & - & - & - & - \\
\hline & & \multicolumn{2}{|c|}{ Euro 3} & 64.85 & - & - & - & - & - \\
\hline & & \multicolumn{2}{|c|}{ Euro 4 SCR } & 27.54 & - & - & - & - & - \\
\hline & & \multicolumn{2}{|c|}{ Euro $5 \mathrm{SCR}$} & 17.35 & - & 12.28 & - & 12.28 & - \\
\hline & & \multicolumn{2}{|c|}{ Euro 6} & 2.56 & - & 1.86 & - & 1.86 & - \\
\hline \multirow[t]{6}{*}{$b$} & Global pollution & \multicolumn{2}{|l|}{ Euro 1} & 62.64 & - & - & - & - & - \\
\hline & & \multicolumn{2}{|l|}{ Euro 2} & 62.28 & - & - & - & - & - \\
\hline & & \multicolumn{2}{|l|}{ Euro 3} & 63.52 & - & - & - & - & - \\
\hline & & \multicolumn{2}{|c|}{ Euro 4 SCR } & 62.07 & - & - & - & - & - \\
\hline & & \multicolumn{2}{|c|}{ Euro $5 \mathrm{SCR}$} & 62.24 & - & 59.39 & - & - & - \\
\hline & & \multicolumn{2}{|c|}{ Euro 6} & 63.17 & - & 50.66 & - & 50.66 & - \\
\hline \multirow[t]{3}{*}{ c } & Noise pollution & \multirow[t]{2}{*}{ Day } & High concentration & 0.54 & 0.64 & 0.54 & 0.64 & 0.54 & 0.64 \\
\hline & & & Low concentration & 1.16 & 1.24 & 1.16 & 1.24 & 1.16 & 1.24 \\
\hline & & Night & Low concentration & 2.02 & 2.10 & 2.02 & 2.10 & 2.02 & 2.10 \\
\hline$d$ & Congestion & \multicolumn{2}{|c|}{ Flowing traffic } & 0.00 & 0.00 & 0.00 & 0.00 & 0.00 & 0.00 \\
\hline & & \multicolumn{2}{|c|}{ Pre-congestion } & 11.13 & 0.00 & 11.13 & 0.00 & 11.13 & 0.00 \\
\hline & & \multicolumn{2}{|c|}{ Congestion } & 25.59 & 0.00 & 25.59 & 0.00 & 25.59 & 0.00 \\
\hline e & Accidents & \multicolumn{2}{|c|}{ Death, serious injuries, accident } & 22.46 & 0.004 & 22.46 & 0.004 & 22.46 & 0.004 \\
\hline \multirow[t]{7}{*}{$f$} & Total & \multicolumn{2}{|c|}{ Euro 1} & 196.69 & 0.65 & - & - & - & - \\
\hline & & \multicolumn{2}{|l|}{ Euro 2} & 195.89 & 0.65 & - & - & - & - \\
\hline & & \multicolumn{2}{|c|}{ Euro 3} & 176.97 & 0.65 & - & - & - & - \\
\hline & & \multicolumn{2}{|c|}{ Euro $4 \mathrm{SCR}$} & 138.20 & 0.65 & - & - & - & - \\
\hline & & Euro 5 & & 128.18 & 0.65 & 110.26 & - & - & - \\
\hline & & Euro 6 & & 114.33 & 0.65 & 101.11 & - & 101.11 & - \\
\hline & & Avera & alue & 158.38 & 0.65 & 105.68 & 0.65 & 101.11 & 0.65 \\
\hline
\end{tabular}


subsequent years, in both scenarios, the technological development leads to the progressive reduction of the most polluting Euro classes: from 2020, only Euro 4-5-6 standards are considered; from 2025, only Euro 5 and Euro 6, and from 2030, only Euro 6 are considered.

\subsubsection{Scenario 1 - Status quo}

Scenario 1 assumes that the modal split remains unchanged over time, in accordance with the values recorded in last 5 years. Starting with the data observed by iMONITRAF! [25], the future quantity of goods transported via the Brenner corridor is calculated (Fig. 4). In 2027, the total transported freight will increase by $27 \%$, from $43.7 \mathrm{Mt}$ to approximately $60 \mathrm{Mt}$. The total freight transported by rail is $17.2 \mathrm{Mt}$, whilst the freight transported by road amounts to $42.8 \mathrm{Mt}$. The unit values of each externality are multiplied by the external unit costs referring to the individual net tonne transported by the two different modes. For noise pollution, congestion and accidents, the same values as those used in Cavallaro's study [34] are used (Table 7 - sections c, d, and e). The unit emissions of local and global air pollution are calculated using the HBEFA [36] emission model, depending on the time horizon variation. Recalling Table 7 , the values of $€ 1.057 / \mathrm{t}_{\text {net }}$ and $€ 0.006 / \mathrm{t}_{\text {net }}$ for road and rail freight transport are considered, respectively. By multiplying the quantify of goods transported by the two transport modes in 2027 by the unit costs, the total annual external costs are obtained. They amount to $€ 45.2 \mathrm{M}$ for road transport and $€ 111.693$ for rail $(0.25 \%$ of the previous value).

In 2035, it is expected that the total transported freight increases by $36 \%$ compared with 2015 , amounting to $48.5 \mathrm{Mt}$ by road and $19.5 \mathrm{Mt}$ by rail. The new external unit costs are recalculated by considering the updated unit values of local and global air pollution in 2035. By applying the unit costs calculated for Phase $2\left(€ 1.01 / t_{\text {net }}\right.$ road and $€ 0.006 / t_{\text {net }}$ rail) to the total freight transported in 2035 , the result is approximately $€ 49 \mathrm{M}$ for road and $€ 126,625$ for rail transport.

By iterating the analysis for each year between 2015 and 2035 and considering the aggregate data, it is expected that from 2015 to 2035 , more than $864 \mathrm{Mt}$ will be transported via the Brenner corridor by road and $348 \mathrm{Mt}$ by rail, for a total of $€ 1002 \mathrm{M}$ generated by road transport and $€ 2.3 \mathrm{M}$ resulting from rail transport. In unitary terms, the total unit cost of freight transport - calculated as the sum of external costs generated by road and rail and divided by total tonnes transported - in South Tyrol in Scenario 1 amounts to $€ 0.82 / t_{\text {net }}$.

\subsubsection{Scenario 2 - Euroregion directive}

In Scenario 2, the modal split changes over the years: 2027 (Phase 1) achieves a balance and 2035 (Phase 2) a reversal of the percentages recorded in 2015 (Fig. 5). In Phase 1, the total freight transported by the two modes increases by $27 \%$, as in Scenario 1, but with a different development: road transport experiences a slight decrease in net tonnes transported (from 31.2Mt to 30Mt), whilst freight transported by rail increases noticeably, from 12.6Mt to 30Mt. Using the external unit costs from Table 7, the new total external costs generated by the two transport modes can be defined $-€ 31.7 \mathrm{M}$ for road and $€ 194,384$ for rail transport (0.61\%). In Phase 2, the total transported freight amounts to approximately $68 \mathrm{Mt}$, of which $48.3 \mathrm{Mt}$ by rail and $19.7 \mathrm{Mt}$ by road. The total external costs referring to the two transport modes are $€ 19.9 \mathrm{M}$ for road transport and $€ 313,105$ for rail transport (1.57\%).

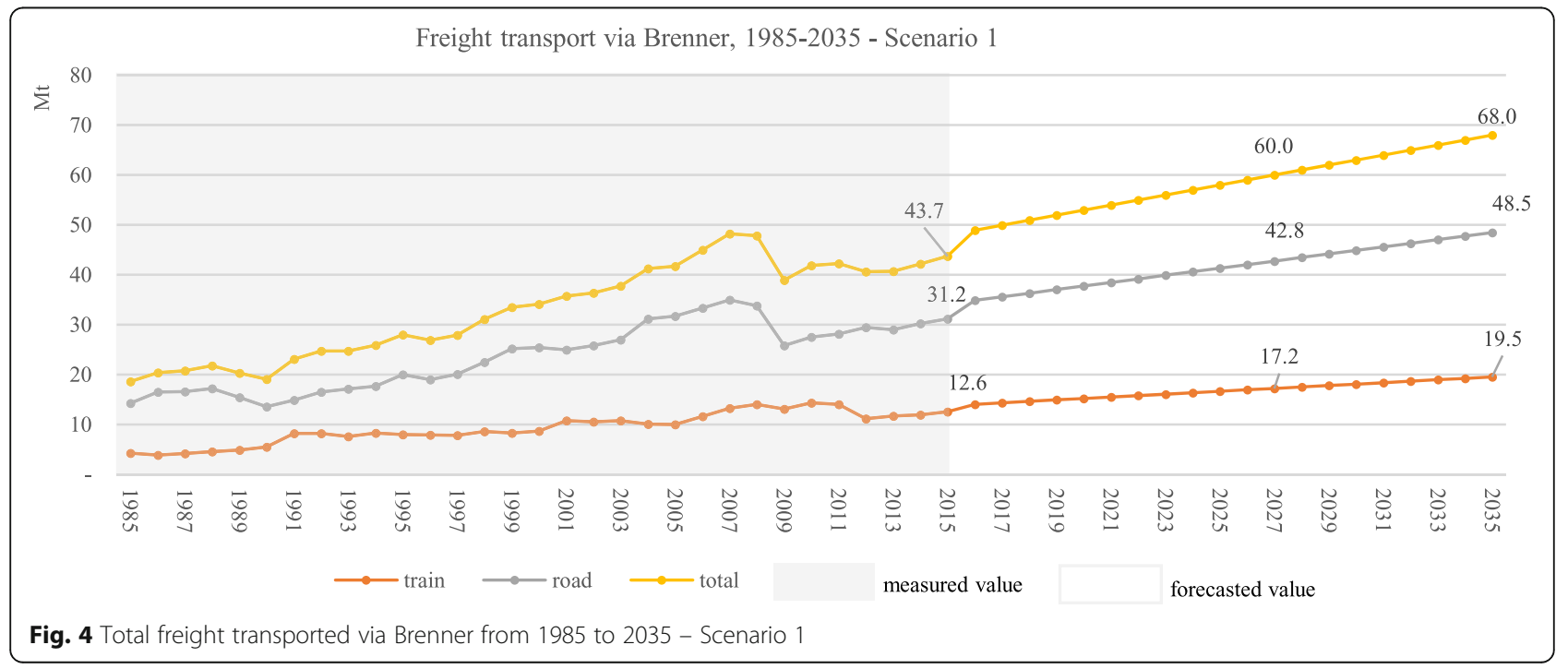




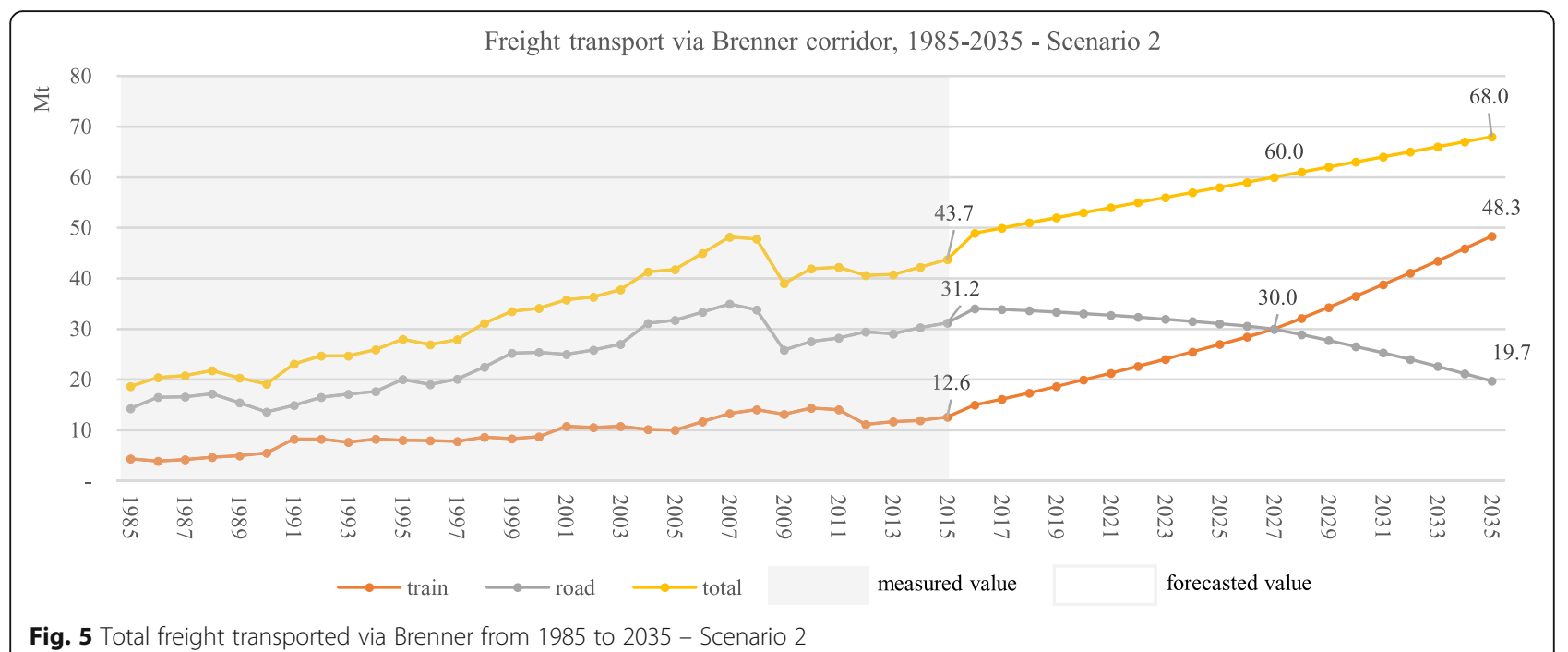

Considering the 2015-2035 timeframe, it is expected that approximately $615 \mathrm{Mt}$ will be transported via the Brenner corridor by road and 598Mt by rail, with external costs totalling $€ 736.6 \mathrm{M}$ and $€ 3.9 \mathrm{M}$, respectively. In this case, the external unit cost drops to $€ 0.61 / t_{\text {net }}$.

\subsection{Comparison between the two scenarios}

The environmental benefit generated by achieving the political objectives proposed by the Tyrol-South Tyrol-Trentino Euroregion varies according to the year of reference. In 2027, the external costs in Scenario 1 and Scenario 2 amount to $€ 45.3 \mathrm{M}$ and $€ 31.9 \mathrm{M}$ respectively, with a difference of $€ 13.4$ M. In 2035 , as a result of the growth in demand, external costs increase for both scenarios, amounting to $€ 49.1 \mathrm{M}$ in Scenario 1 and $€ 20.2 \mathrm{M}$ in Scenario 2. The difference, amounting to up to $€ 28.9 \mathrm{M}$, between the two scenarios is due to a different modal split. Considering the entire 20-year period (Fig. 6), the amount of external costs produced in Scenario 1 totals $€ 1002 \mathrm{M}$, whereas it decreases to approximately $€ 740 \mathrm{M}$ in Scenario 2 . Therefore, the saving guaranteed by Scenario 2 totals $€ 262$ M, with a $26 \%$ reduction in costs.

Analysing the individual external effects, the largest contribution is made by global pollution, which accounts for approximately $40 \%$ in both scenarios, followed by local pollution (approximately 30\%) and accidents (approximately 17\%) (Figs. 7 and 8). Though the difference is not evident in terms of percentage, in absolute values the external effects undergo a significant decrease $(-26 \%)$ in Scenario 2: for instance, the contribution of global pollution decreases from $€ 408.48 \mathrm{M}$ to $€ 300.00 \mathrm{M}$.

Lastly, in unit terms, one net tonne of freight transported in the South Tyrolean stretch of the Brenner

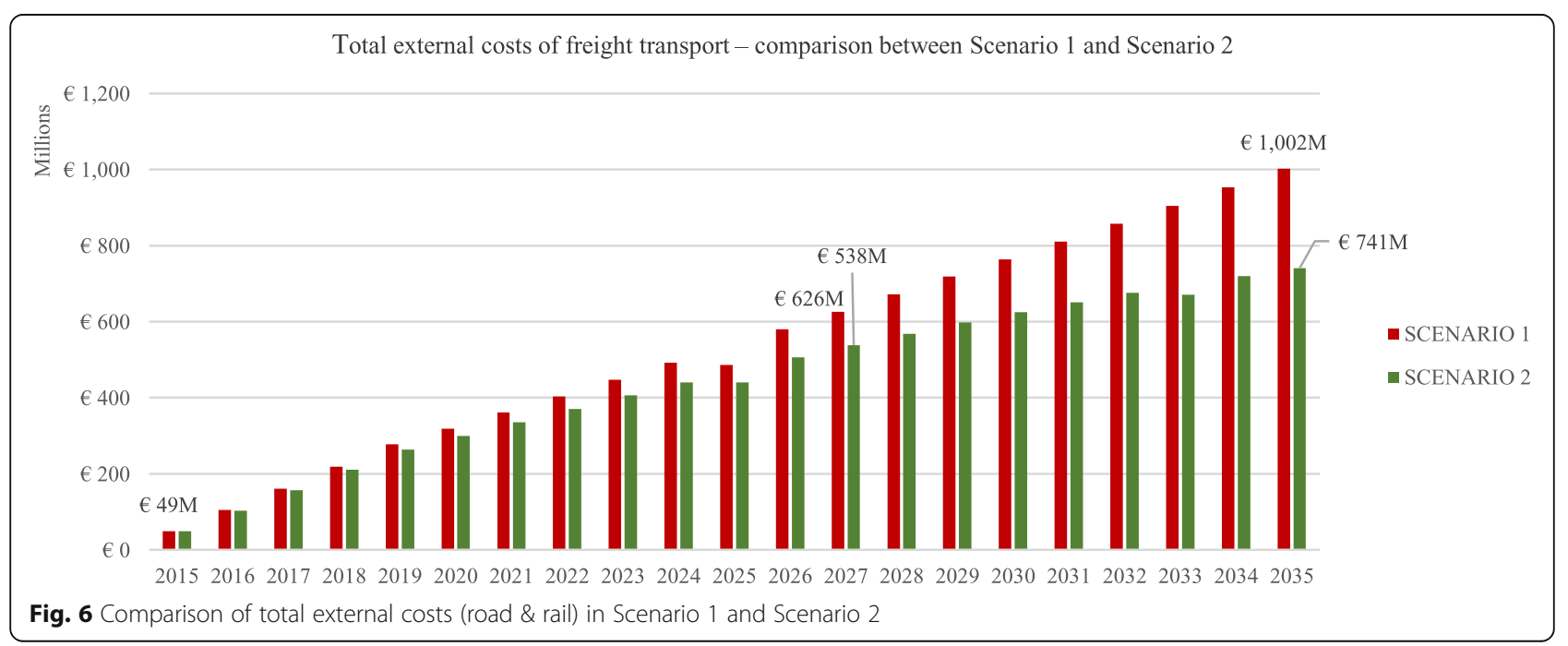


External costs - Scenario 1

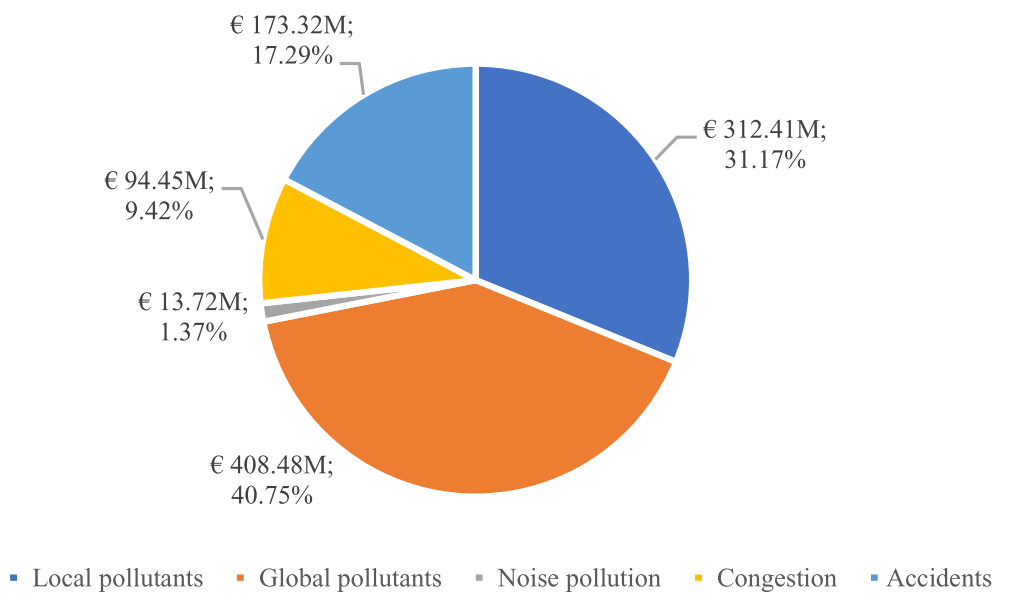

Fig. 7 External costs - Scenario 1 (absolute values and percentages)

corridor, according to the modal share in Scenario 2, generates lower costs than Scenario 1, with values decreasing from $€ 0.82 / t_{\text {net }}$ to $€ 0.61 / t_{\text {net }}(-26 \%)$.

\section{Conclusions}

Brenner is the main transalpine corridor for volumes of goods transported and further growth is expected over the coming years. If the modal split remains similar to the last 5 years ( $71 \%$ by road and $29 \%$ by rail), the population living along the corridor will suffer even greater consequences in terms of external effects - these include air pollution (especially $\mathrm{NO}_{2}$, which records constant excesses compared to the EU threshold), noise pollution and congestion. These external costs for the next 20 years have been quantified at $€ 1002 \mathrm{M}$, a value equal to one fifth of the annual expenses incurred by the Autonomous Province of Bolzano (approximately $€ 5500 \mathrm{M}$ in 2016).

This value derives from the initial assumptions highlighted in section 5 , which have to be considered in the interpretation of the results. They include the forecast about future tons transported along the Brenner line, the preliminary definition of a road and rail vehicle type, the analysis limited to the TTW emissions, as well as the absence of congestion for railway. Furthermore, the selection of a unitary value for each transport externality is a critical issue, due to the numerous scientific and economic sources of uncertainty. In this paper, we have decided to adopt Ricardo-AEA [4] as a reference document, in line with the long-term objectives set on a

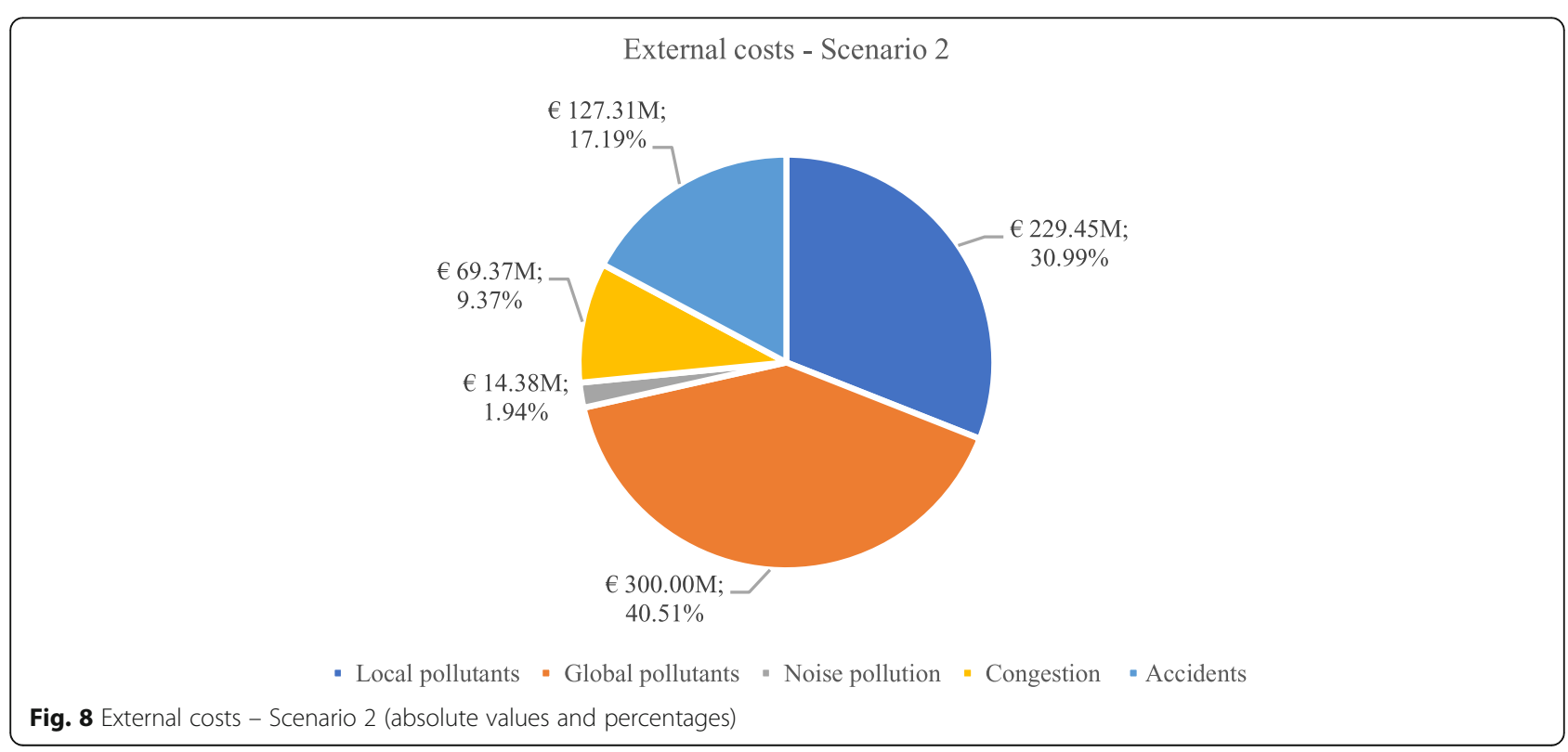


continental level. Other unitary values may obviously lead to different results.

In order to address the critical condition along the Brenner, the Euroregion has proposed an ambitious objective: to reverse the percentages registered in last 5 years by 2035 , thus achieving a modal share similar to the one recorded along the Gotthard axis. The calculations provided in Section 5 reveal that this configuration is expected to guarantee an external cost saving of approximately $€ 262 \mathrm{M}$. This is more than twice the amount of annual subsidies given to public transport in South Tyrol and amounts to approximately $4.7 \%$ of the annual public expenditure of the Autonomous Province of Bolzano.

To achieve this result, many measures have to be taken jointly. In Section 4, they have been divided into infrastructure/services, service management and regulatory measures. Beyond the theoretical framework of reference, it is appropriate to consider the ones for which implementation has been planned. Firstly, significant support could result from the commissioning of the new high-speed/high-capacity railway line, whose central section - the BBT - is currently under construction. However, the construction of the tunnel alone, unless accompanied by other regulatory measures, may have negative consequences in terms of external effects, as a result of the additional demand generated [37]. In this sense, the incentive for combined transport along the regional stretch of the Brenner corridor, recently planned by a resolution of the Autonomous Province of Bolzano [19], may be an important accompanying measure. On the other hand, measures for discouraging road traffic, such as those adopted in part by nearby Tyrol, must be considered as integrative. However, they have to be planned in an integrated way and not -as in some cases still happens today- only in specific stretches of the line. This approach leads to the consequences that are registered with great emphasis by the news [38] and that are counterproductive in terms of management of the traffic. The Swiss case of the performance-related heavy vehicle charge (HVC) is an interesting approach, valid for a broader territorial area. Introduced in 2001, this federal charge is based on a set of parameters, including the weight of the vehicle, the Euro class and the amount of kilometres driven in Switzerland and the principality of Liechtenstein. HVC is valid for all heavy vehicles exceeding 3.5 and it includes a constant and gradual update of the fares. Two-thirds of the revenues are adopted to realize the new HS railway infrastructures, while the remaining one-third is distributed to the cantons, to be invested in the improvement of road infrastructures.

Alongside these initiatives, we must not overlook measures for reducing the pollution produced by road vehicles, such as the technological improvement of vehicle fleets and the use of alternative fuels. Though they do not act directly on modal diversion, they may contribute to reducing local and global emissions and, in some cases, noise pollution [39]. In this sense, the Bolzano hydrogen centre is an interesting experiment (the first in Italy), which could be replicated at other points of the network to create a real hydrogen corridor. Likewise, developments in Liquefied Natural Gas (LNG) show interesting potential for heavy vehicles - these should be considered, given that compared with a Euro 6 diesel-fuelled vehicle, LNG reduces $\mathrm{NO}_{\mathrm{x}}$ emissions by more than $60 \%$ and TTW $\mathrm{CO}_{2}$ emissions by $10 \%$.

Only a combination of various initiatives might contribute to a real reduction in external costs generated by freight transport without a simultaneous reduction in demand, in accordance with the indications of the White Paper on Transport. The path towards this objective seems long, and it will inevitably involve the growth in the railway sector.

\section{Endnotes}

${ }^{1}$ The project, which began in 2009 , envisages the involvement of three States and five regions to ensure the route connecting Italy to Germany has a lower environmental impact. Some of the measures include hydrogen vehicles (distributors every $100 \mathrm{~km}$ ), freight transport by rail, energy from local renewable sources, efficiency, and energy savings.

${ }^{2}$ The quantification and monetization of transport externalities have been object of numerous studies [4149]. As discussed in [50] referring to GHG emissions, several technical, economic and decisional sources of uncertainty determine a high range of values, which includes several orders of magnitude. This aspect has to be kept in mind when analysing the results presented in this section.

${ }^{3}$ For a more in-depth analysis on the method used to calculate the unitary quantities, refer to the study conducted by Cavallaro [34].

\section{Acknowledgments \\ Not applicable.}

\section{Availability of data and material}

Not applicable.

\section{Funding}

This work has been partially funded by the Autonomous Province of Bolzano-Alto Adige through the research grant No. ZBA1F6886A. Please note that this statement has to be included in the paper if published.

\section{Authors' contributions}

All authors read and approved the final manuscript.

Competing interests

The authors declare that they have no competing interests. 


\section{Publisher's Note}

Springer Nature remains neutral with regard to jurisdictional claims in published maps and institutional affiliations.

\section{Author details}

'Department of Architecture and Arts, IUAV University of Venice, Santa Croce 191, I-30135 Venice, Italy. ²Eurac Research, Institute for Regional

Development, Viale Druso 1, I-39100 Bolzano-Bozen, Italy.

Received: 12 June 2018 Accepted: 25 September 2018

\section{Published online: 22 November 2018}

\section{References}

1. Eurostat (2017) Freight transport statistics - modal split. http://ec.europa.eu/ eurostat/statistics-explained/index.php/Freight_transport_statistics_-_ modal_split. Accessed 25 April 2018

2. EU (2017) EU Transport in figures - Statistical Pocketbook 2017. https://ec. europa.eu/transport/facts-fundings/statistics/pocketbook-2017_en. Accessed 15 April 2018

3. MTRU (2017) Impact on congestion of transfer of freight from road to rail on key strategic corridor. Campaign for better transport. https://www. bettertransport.org.uk/sites/default/files/research-files/cross-modal-freightstudy.pdf. Accessed 13 April 2018

4. Ricardo-AEA (2014) Update of the handbook of external costs of transport. In: Final Report. Ricardo-AEA, UK

5. Royal Academy of Engineering (2015). The transport congestion challenge getting the most out of the UK's road and rail networks. https://www.raeng. org.uk/RAE/media/Publications/Reports/The-Transport-CongestionChallenge.pdf. Accessed 11 April 2018

6. European Federation for Transport and Environment AISBL (2017) Roadmap to climate-friendly land freight and buses in Europe. https://www. transportenvironment.org/publications/roadmap-climate-friendly-landfreight-and-buses-europe. Accessed 23 April 2018

7. EU (2016) II trasporto delle merci su rotaia nell'UE non è ancora sul giusto binario. Relazione speciale n 8 (IT). doi:https://doi.org/10.2865/9108

8. Van Essen H, Bello O, Dings J, 2003. To Shift or not to Shift, that's the Question. The Environmental Performance of Freight and Passenger Transport Modes in the Light of Policy Making. Delft, CE

9. De Langhe K (2017) The importance of external costs for assessing the potential of trams and trains for urban freight distribution. Res Transp Bus Manag 24:114-122

10. Janic M, Vleugel J (2012) Estimating potential reductions in externalities from railroad substitution in trans-European freight transport corridors. Transp Res Part D: Transp Environ 17:154-160

11. Booz Allen Hamilton Ltd. (2007) Estimated carbon impact of a new northsouth line. Research report. http://webarchive.nationalarchives.gov.uk/+/ http:/www.dft.gov.uk/pgr/rail/researchtech/research/newline/carbonimpact. pdf. Accessed 12 May 2018

12. Behrends S (2017) Burden or opportunity for modal shift? Embracing the urban dimension of intermodal road-rail transport. Transp Policy 59:10-16

13. Janic M (2007) Modelling the full costs of intermodal and road freight transport networks. Transp Res D 12:33-44

14. Libardo A, Nocera S (2008) Transportation elasticity for the analysis of Italian transportation demand on a regional scale. Traffic Eng Control 49-5:187-192

15. Nocera S, Cavallaro F (2012) Economic evaluation of future carbon impacts on the Italian highways. Procedia - social and. Behav Sci 54:1360-1369

16. EU (2011) White paper on transport. doi:https://doi.org/10.2832/30955

17. Sutter D, Weber F, Bieler C, Sedlacek N (2017). External costs in mountain areas. Infras, Zürich

18. Lückge H, Heldstab J, Cavallaro F, Vivier S, Kistler R, Joos-Widmer N (2017) iMONITRAF! Annual Report 2016. Political support for Toll Plus \& agenda setting for a new phase. http://www.imonitraf.org/DesktopModules/ ViewDocument.aspx?DocumentID=fak2jWTCaHk=. Accessed 26 March 2018

19. Deliberazione n.01/2018 della Giunta del GECT Euregio Tirolo-Alto AdigeTrentino (2018) Strategia dell'Euregio per il trasferimento del traffico dalla strada alla rotaia: obiettivi strategici per una politica dei trasporti comune, coerente e sostenibile lungo l'asse del Brennero. http://www.provinz.bz.it/ news/de/news.asp?news_action $=300 \&$ news_image_id $=975798$

20. Nocera S, Cavallaro F (2016) Economic valuation of well-to-wheel CO2 emissions from freight transport along the main transalpine corridors.
Transp Res Part D: Transp Environ 47:222-236. https://doi.org/10.1016/j.trd. 2016.06.004

21. Convenzione delle Alpi (1995) Convenzione quadro. http://www.alpconv. org/it/convention/framework/default.html. Accessed 12 April 2018

22. Protocollo "Trasporti" (2006) Protocollo di attuazione della convenzione delle Alpi del 1991 nell'ambito dei trasporti. http://www.alpconv.org/it/ convention/protocols/Documents/trasporti_it.pdf. Accessed 15 April 2018

23. Aa. VV., (2001) Declaration of Zurich. http://www.zurich-process.org/ fileadmin/data/webcontent/Webcontent/Sonstige_Dateien/Declaration_of_ Zurich_en_2001.pdf

24. EUSALP (2018) EU Strategy for the Alpine Region. https://www.alpineregion.eu/. Accessed 20 March 2018

25. iMonitraf! (2018) Monitoring of road traffic related effects in the Alpine Space and common measures. http://www.imonitraf.org/i4Def.aspx?Tabld= 364\&lang=en. Accessed 9 April 2018

26. AlplnnoCT (2018) Alpine Innovative for Combined Transport http://www. alpine-space.eu/projects/alpinnoct/en/about. Accessed 25 April 2018

27. Asfinag (2018) GO-box for HGV and bus. https://www.asfinag.at/toll/go-boxfor-hgv-and-bus/. Accessed 25 April 2018

28. Tirol Unser Land (2018) Divieti di circolazione secondo la legge sulla tutela dalle emissioni in Atmosfera https://www.tirol.gv.at/it/ambiente/divieti-dicircolazione-secondo-la-legge-sulla-tutela-dalle-emissioni-in-atmosfera/ Ordinanza del Presidente della regione del 18 maggio 2016. Divieto di circolazione

29. Deliberazione n.655/2017 della Giunta provinciale di Bolzano-Alto Adige (2017) Criteri per l'incentivazione del trasporto combinato

30. Deliberazione n.12/2009 della Giunta del GECT Euregio Tirolo-Alto AdigeTrentino (2009) Strategia comune concordata per il graduale trasferimento del traffico merci dalla strada alla rotaia

31. Deliberazione n. 15/2015 della Giunta del GECT Euregio Tirolo-Alto AdigeTrentino (2015) Progetto Euregio - Pacchetto di misure per il trasferimento del trasporto merci dalla strada alla rotaia

32. Cappelli A, Nocera S (2006) Freight modal split models: data base, calibration problem and urban application. WIT Trans Built Environ 89:369375. https://doi.org/10.2495/UT060371

33. EP, European Parliament (2015) Policy department B - structural and cohesion policies. Freight on road: why EU shippers prefer truck to train. http://www.europarl.europa.eu/RegData/etudes/STUD/2015/540338/IPOL STU(2015)540338_EN.pdf. Accessed 25 April 2018

34. Islam D, Md Z, Ricci S, Nelldal B (2016) How to make modal shift from road to rail possible in the European transport market, as aspired to in the EU transport white paper 2011. Eur Transp Res Rev 8:18

35. Cavallaro F (2018) Policy implications from the economic valuation of freight transport externalities along the Brenner corridor. Case Stud Transp Policy. https://doi.org/10.1016/j.cstp.2017.11.008

36. Infras (2014) The Handbook Emmision Factors for Road Transport (HBEFA). http://www.hbefa.net/e/index.html. Accessed 23 April 2018

37. Nocera S, Cavallaro F (2014) A methodological framework for the economic evaluation of CO2 emissions from transport. J Adv Transp 48:138-164

38. Corriere della Sera (2017). Cento km di coda sull'Autobrennero: il lunghissimo serpentone di Tir. https://www.corriere.it/cronache/17_ottobre_ 04/cento-km-coda-sull-autobrennero-lunghissimo-serpentone-tir-b063b604a949-11e7-8539-6c9b026c835a.shtml. Accessed 23 April 2018

39. Ayyildiz K, Cavallaro F, Nocera S, Willenbrock R (2017) Reducing fuel consumption and carbon emissions through eco-drive training. Transp Res F Psychol Behav 46:96-110. https://doi.org/10.1016/j.trf.2017.01.006

40. EUR-Lex (2018) Sintesi della legislazione dell'UE. Trasporti. https://eur-lex. europa.eu/summary/chapter/transport.html?locale=it\&root_default=SUM_1_ CODED\%3D32. Accessed 12 April 2018

41. Giannopoulos GA (2009) Towards a European ITS for freight transport and logistics: results of current EU funded research and prospects for the future. Eur Transp Res Rev 1:147-161

42. INFRAS/IWW (1995) External Costs of Transport Karlsruhe/Zurich/Paris

43. Danielis R (2001) La teoria economica e la stima dei costi esterni dei trasporti. http://www2.units.it/danielis/wp/wp079.pdf. Accessed 20 May 2018

44. Maibach M, Schreyer C, Sutter D, van Essen H P, Boon B H, Smokers R, Schroten A, Doll C, Pawlowska B, Bak M, (2008) Handbook on estimation of external costs in the transport sector internalisation. Measures and Policies for All external Cost of Transport (IMPACT)

45. Santos G, Behrendt H, Maconi L, Shirvani T, Teytelboym A (2010) Externalities and economic policies in road transport. Res Transp Eco 28:2-45 
46. CE Delft, INFRAS, Fraunhofer-ISI (2011) External costs of transport in Europe. Update Study for 2008. https://www.cedelft.eu/publicatie/external_costs_of transport_in_europe/1258. Accessed 13 Apr 2018

47. Becker U J, Becker T, Gerlach J (2012). The True Costs of Automobility: External Costs of Cars. Overview on existing estimates in EU-27. https:// stopclimatechange.net/fileadmin/content/documents/move-green/The_ true_costs_of_cars_EN.pdf. Accessed 15 Apr 2018

48. Litman T (2016) Transportation Cost and Benefit Analysis: Techniques, Estimates and Implications. Air Pollution Costs. VTPI, Victoria Transport Policy Institute, Victoria. www.vtpi.org/tca/tca0510.pdf. Accessed 20 April 2018

49. Nocera S, Ruiz-Alarcón Quintero C, Cavallaro F (2018) Assessing carbon emissions from road transport through traffic flow estimators. Transp Res C 95:125-148. https://doi.org/10.1016/j.trc.2018.07.020

50. Nocera S, Irranca Galati O, Cavallaro F (2018) On the uncertainty in the economic valuation of carbon emissions from transport. JTEP 52:68-94

\section{Submit your manuscript to a SpringerOpen ${ }^{\circ}$ journal and benefit from:}

- Convenient online submission

- Rigorous peer review

- Open access: articles freely available online

- High visibility within the field

- Retaining the copyright to your article

Submit your next manuscript at $\boldsymbol{\nabla}$ springeropen.com 